its habits in winter, however, we are told "little is known." But further research into literature and inquiry among observers should surely have corrected this.

A smear on the general attractiveness and beauty of the second volume is unfortunately to be noticed in the shape of a footnote wherein one of the contributors indulges in a petulant attack on reviewers. As the editor expressly repudiates responsibility for the statements made in the note he is doubtless alive to their exceedingly bad taste; but why deface the pleasing pages of the book with an acrid expression of pique which can only be of interest to one person in the world?

At the end of the work there are to be chapters on rare British birds, classification of British birds, distribution and migration of British birds, bird watching and photography, and bibliography. With regard

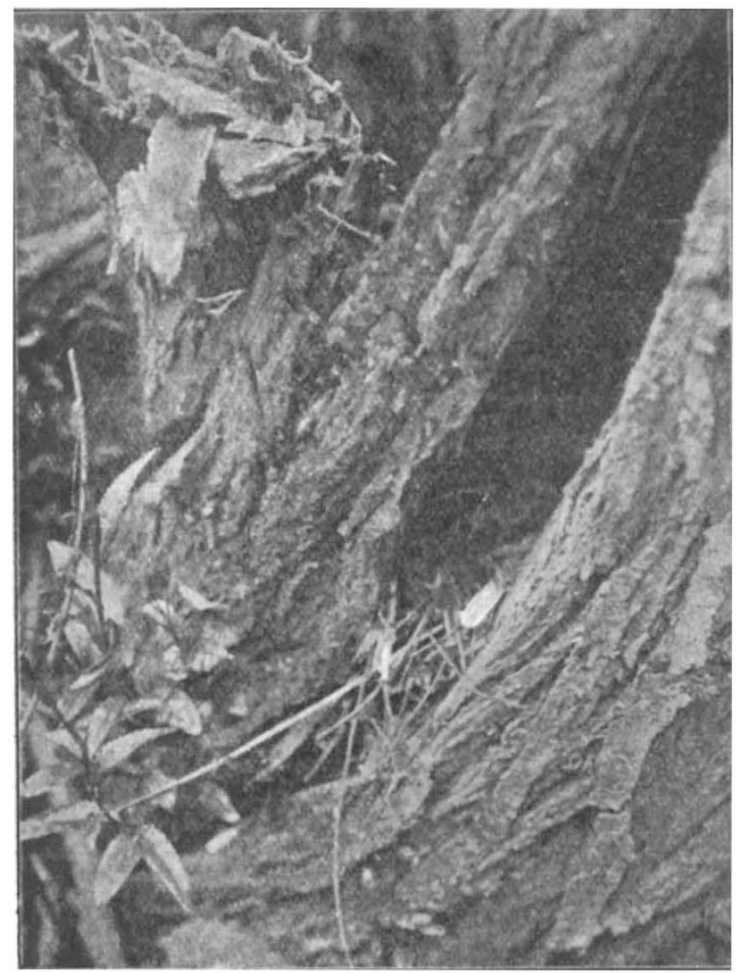

Photo by E. L. Turner.

FIG. 2.-Tree-creeper's Nest tn a crevice in a Tree. From "The British Bird-Book."

to the illustrations, the artists include Winifred Austin, G. E. Lodge, H. Grönvold, G. E. Collins, and A. W. Seaby. The coloured plates in the present volumes are exceedingly pleasing and charming in every way, and they certainly do answer the purpose for which they have been designed. Their object is to supply something more than a portrait of each species for purposes of identification. Each picture is, with few exceptions, to offer a study of some habit of the bird or of one of its most characteristic and striking attitudes; it is to show the bird in its natural surroundings, and the thirty-four plates in these volumes are, on the whole, quite a success. In addition, we have a coloured plate of eggs, numerous photographs of nests and eggs and young, an outline map of the world, showing the six zoo-geographical NO. $2 \times 52$, VOL. 857 regions, and a diagram explaining the names of the various external parts and portions of the plumage of a bird. An index is promised at the end of the book, which is to be completed in twelve of these sections or volumes.

The twenty plates of eggs which, with very short letterpress, are meant to supplement the "Sketch Book of British Birds," can hardly be said to be worth publication. ${ }^{1}$

The book is, in fact, too cheap. We cannot expect twenty coloured plates for five shillings, and the cheap reproduction has been a failure. Yet it was hoped that by having a faithful representation of one normal specimen of each species a key would be furnished by which identification might be made comparatively easy. This hope would have been better sustained, poor as the figures are, had they been correctly named. But, turning to plate iii., we find the egg of the black-throated thrush referred to the rock thrush and vice versa, that of the "American thrush" (Turdus migratorius) to the redwing, that of the redwing to the missel thrush, and that of the missel thrush to the American thrush; while on plate xv. the eggs of the purple sandpiper and little stint do duty for one another. We have not had patience to go through all of them. This deplorable confusion has been caused by the careless insertion of the reference numbers. But it is fatal to the key, and will prove fatal to the beginner's attempt to identify eggs. A few lines of letterpress are devoted to each species. Turning to that relating to this plate $x v$., we find the wood sandpiper called the wood "tattler," an American name not in use in England, and the information that the pectoral sandpiper is an American species the nest of which is built on high grassy slopes in Lapland! It is no longer correct to say that the eggs of the knot are still unauthenticated.

\section{THE SEA-OTTER. ${ }^{2}$}

$\mathrm{SOME}$ twenty years ago, in the days of the Bering Sea question, Captain Snow was well known as an authority on certain of the fur-seal fisheries of the North Pacific, and he was, and still is, known as one of the few authorities on the geography of the Kurile Islands. He has now written a pleasant book telling some of his manifold adventures in this region of the world, and, above all, relating his experiences in pursuit of sea-otter. There is an interest which amounts to fascination in this singular animal. Fifty years ago it was comparatively plentiful all round the coast of the North Pacific, from California and Oregon to Kamtschatka and the Kuriles, though doubtless already much less abundant than in Steller's time, more than a hundred years before. But nowadays it has dwindled to very small numbers, here and there among the Aleutian and Kurile Islands, and these small numbers dwindle more and more every year. I know of no living naturalist who has seen the creature in its haunts, nor has any zoological garden ever possessed it. Once upon a time, by the way, I spent a fortnight on Copper Island, at the north end of which, five or six miles from my hut, was a large rookery of sea-otters; but while I was provided with passports giving me perfect freedom of access to the seal-rookeries, there was no word said about sea-otters; and day after day a polite functionary made excuses and apologies, a Cossack guard made

1 “'British Birds' Eggs." By A. F. Lydon. Pp. $62+20$ plates. (London: S.P.C K., Igro.) Price 5 s.

2 "In Forbidden Seas." Recollections of Sea-Otter Hunting in the Kurils. By H. Y. Snow, F.R.G.S. Pp. xiv +303 . (London: Edward Arnold, xgro.) Price I2s. 6 d. net. 
neither the one nor the other, and I came away without ever seeing the sea-otter.

While allied to the ordinary otters, the sea-otter has many peculiarities of structure which have scarcely yet been sufficiently weighed and discussed. Its small, but immensely powerful skull seems disproportionate to its big body; its forepaws are diminutive, while its hind ones are long and almost seal-like; its teeth are unique in their great smooth, rounded crowns, with which the animal crunches the crabs, sea-urchins, and shell-fish that make up most of its diet. Its fur is the finest and richest of all furs, soft, deep, and silky, uniform in colour save for the white or grey head, jet black in the finer skins, or interspersed with silvery hairs in the finest of all. A fullgrown animal measures 4 to $4 \frac{1}{2}$ feet in length, but the skin of such an animal easily stretches out to 6 feet walk the toes are doubled back under the sole (see illustration).

The mother otter swims upon her back, carrying her pup in her forepaws. When she dives for food she leaves the pup floating on its back, but when chased she dives with it, gripping it by the scruff of the neck, like a cat with its kitten, and she never deserts her pup until the poor little beast is perhaps drowned by her constant diving.

Captain Snow gives us some account of the number of otters killed in the Kuriles, which number between 1872 and 1881 varied from about 300 to $I_{500}$ a year. In the next decade (I 882 to I89I) about I200 were taken in all, by both foreign and Japanese schooners; between 1892 and I901 about 800 were taken, and from I902 to I909 only about 350 in all. We may compare these figures with Captain Hooper's statistics for the

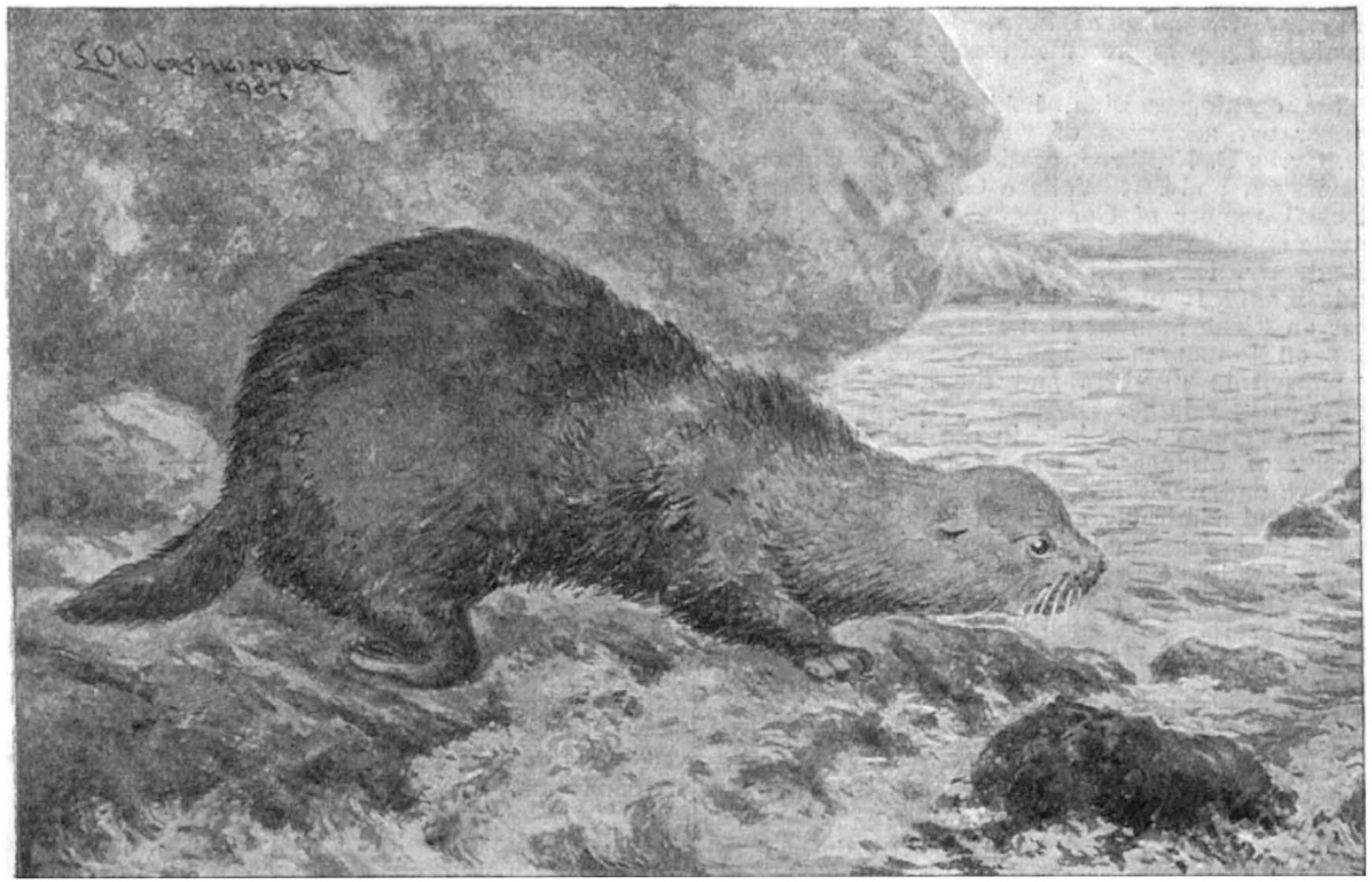

Sea Otter. From "In Forbidden Seas."

in length or more, and is worth nowadays something like $£ 300$ or $£ 400$.

The habits of the sea-otter are very singular. His natural home is on the great beds of "kelp " (Macrocystis), which fringe the rocky coast of the North Pacific, and these great kelp beds make calm water, though the surf be roaring and breaking just outside. The kelp beds are dense enough for the otters to lie upon, and here in old days they were so tame that they used to "stand with head and forepaws out of the water," staring at the hunter and his gun. The creature is handy with its forepaws, and has been again and again described ever since Steller's time as dandling and nursing its young in them; it holds its food almost as a squirrel does, and boxes its young or its companions, like a couple of cats at play. But its hind feet are for swimming only; it walks with difficulty, generally drawing up its hind feet both together and jumping forward, and, as Captain Snow assures us, when it attempts to NO. 2 I 52 , VOL. 85$]$
Aleutian Islands, where more than 58,000 otters were taken in the twenty-four years from 1873 to I896.

But for statistics and other technical details we must go to Hooper and Stejneger, Elliott and Allen, for statistics are not much in our good Captain's line. $\mathrm{He}$ is a sailor and an adventurer, and wherever otters were or seals, there was his Treasure Island. $\mathrm{He}$ has much to tell and very little to conceal. We hear of his love episodes with this or that young lady whose name ended in San ("it was always happening in those days"), and again of his raids, not bloodless, on Japanese or Russian "rookeries"; for he would seem to have been early aware that "there runs no law of God nor man to the north of forty-three." In short, our gallant Captain belongs to a very lovable and all but vanished type, rarer even and better than the sea-otter, the good old delightful breed of the pirate and the robber.

D. W. T. 